\title{
The presence of anemia in patients with leg ulcer: laboratory test
}

\author{
Presença de anemia em pacientes com úlcera da perna: testes laboratoriais \\ La presencia de anemia en pacientes con úlcera de la pierna: prueba de laboratorio
}

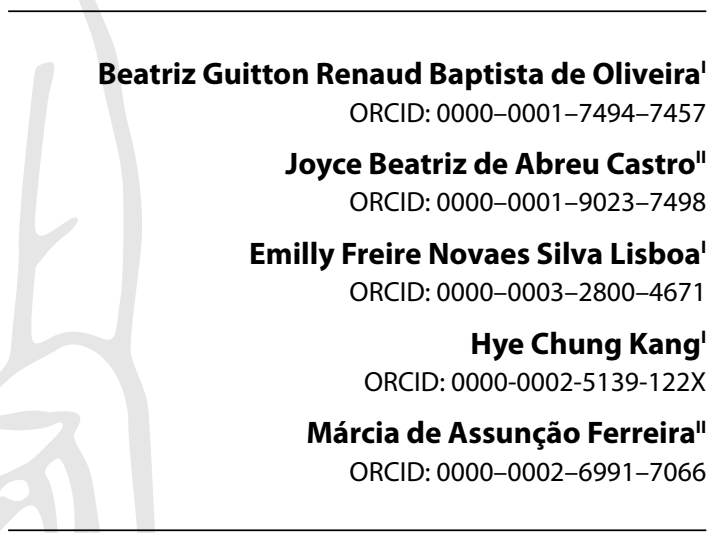

'Universidade Federal Fluminense. Niterói, Rio de Janeiro, Brazil.

"Universidade Federal do Rio de Janeiro. Rio de Janeiro,

Rio de Janeiro, Brazil.

How to cite this article:

Oliveira BGRB, Castro JBA, Lisboa EFNS, Kang HC, Ferreira MA

The Presence of Anemia in patients with Leg Ulcer:

Laboratory Tests. Rev Bras Enferm. 2022;75(1):e20210064. https://doi.org/10.1590/0034-7167-2021-0064

\section{Corresponding author:}

Joyce Beatriz de Abreu Castro

E-mail: joycebeatrizcastro@hotmail.com

EDITOR IN CHIEF: Antonio José de Almeida Filho ASSOCIATE EDITOR: Alexandre Balsanelli

Submission: 06-29-2020

Approval: 04-22-2021

\begin{abstract}
Objective: To evaluate the presence of anemia in patients with chronic lower limb ulcers based on profile and hematometric indices. Method:This is a cross-sectional study carried out in a university hospital in Rio de Janeiro. The sample was composed of 64 participants with lower limb ulcers and evolution time greater than 12 weeks. Data was collected between May/2016 and December/2017 from hematological analyses, records from medical records, and wound assessment form. Results: 36 (56.2\%) were male; 38 (59.4\%) between 60 and 80 years old; $56(87.5 \%)$ with chronic diseases and $52(81.2 \%)$ with venous ulcers. 6 years mean of active ulceration. Anemia was detected in 36 (56.2\%), 27 (75\%) of which were normochromic and normocytic; 14 (38.8\%) had deficiency anemia recorded in their medical chart. Conclusion: The low hemoglobin concentration is recurrent among the participants characterizing an anemia condition, whose profile reveals congruence to the anemia of chronic disease. Descriptors: Anemia; Erythrocyte Indices; Lab Tests; Leg Ulcer; Nursing Assessment.
\end{abstract}

\section{RESUMO}

Objetivo: Avaliar a presença de anemia em pacientes com úlceras crônicas de membros inferiores a partir do perfil e dos índices hematimétricos. Método: Estudo seccional realizado em um hospital universitário do Rio de Janeiro. Amostra composta por 64 participantes com úlceras de membros inferiores e tempo de evolução maior que 12 semanas. Dados coletados entre maio/2016 e dezembro/2017, a partir de análises hematológicas, registros nos prontuários e em formulário de avaliação da ferida. Resultados: 36 (56,2\%) eram do sexo masculino; 38 (59,4\%) entre 60 e 80 anos; 56 (87,5\%) com doenças crônicas e $52(81,2 \%)$ com úlceras venosas. Média de 6 anos de úlcera ativa. Detectou-se anemia em 36 (56,2\%), sendo 27 (75\%) normocrômica e normocítica; 14 (38,8\%) apresentavam anemia carencial registrada em prontuário. Conclusão: $\mathrm{A}$ baixa concentração de hemoglobina é recorrente entre os participantes, caracterizando um quadro de anemia cujo perfil revela congruência ao da anemia da doença crônica.

Descritores: Anemia; Índices de Eritrócitos; Testes Laboratoriais; Úlcera da Perna; Avaliação em Enfermagem.

\section{RESUMEN}

Objetivo: Evaluar la presencia de anemia en pacientes con úlceras crónicas de miembros inferiores desde el perfil e índices hematimétricos. Método: Este estudio seccional transcurrió en un hospital universitario de Río de Janeiro, con una muestra de 64 participantes con úlceras en los miembros inferiores y tiempo de evolución superior a 12 semanas. Los datos se recopilaron entre mayo/2016 y diciembre/2017 investigando los análisis hematológicos, registros en las historias clínicas y formularios de evaluación de la herida. Resultados: 36 (56,2\%) eran hombres; $38(59,4 \%)$ tenían entre 60 y 80 años; 56 (87,5\%) padecían de enfermedades crónicas y $52(81,2 \%)$, de úlceras venosas. El promedio era de 6 años de úlcera activa. Se detectó anemia en 36 (56,2\%), siendo que en 27 (75\%) era normocrómica/normocítica; 14 $(38,8 \%)$ presentaban anemia carencial registrada en la historia clínica. Conclusión: La baja concentración de hemoglobina es recurrente entre los participantes caracterizando un cuadro de anemia que coincide con el de anemia de enfermedad crónica.

Descriptores: Anemia; Índices de Eritrocitos; Pruebas de Laboratorio; Úlcera de la Pierna; Evaluación de Enfermería. 


\section{INTRODUCTION}

Different mechanisms can cause the anemic syndrome; among them, the ones characterized by disturbances in iron homeostasis stand out, as they cause deficient hemoglobin synthesis $(\mathrm{Hb})^{(1)}$. In these cases, the hemoglobin concentration in the blood is usually below the limit advised as usual ${ }^{(2)}$. Although hemoglobin concentration corresponds to the laboratory parameter universally used to diagnose anemia ${ }^{(2)}$, other parameters such as erythrocyte count and hematocrit are usually also decreased and can assist in the diagnosis ${ }^{(2)}$.

Typical $\mathrm{Hb}$ reference values for the definition of blood anemia vary according to the sex and age of the individual, considering the levels of this analyte in a group of individuals representative of a population ${ }^{(4)}$. Thus, laboratorially, the anemic will be defined by the limit of the $\mathrm{Hb}$ level below $13,0 \mathrm{~g} / \mathrm{dL}$ in adult men and less than $12,0 \mathrm{~g} / \mathrm{dL}$ in adult women ${ }^{(3-4)}$.

Although anemia resulting from iron deficiency is the most prevalent, the proportion varies according to the local conditions of the population examined ${ }^{(5-6)}$; this article discusses a type of anemia called anemia of chronic disease (ACD). A very common clinical syndrome, in which its total incidence is surpassed only by iron deficiency anemia, being more prevalent among elderly individuals $s^{(1-2,7)}$.

Anemia can be classified according to the size and concentration of $\mathrm{Hb}$ in the red cells through the data offered by the hematimetric indices. In terms of cell volume, they are divided into microcytic, normocytic, or macrocytic. According to the cell content, they can be of the hypochromic or normochromic type ${ }^{(3)}$.

The interest in this theme arose from a Randomized Clinical Trial (RCT) conducted by the researchers-authors of this study, which sought to analyze the effectiveness of using platelet-rich plasma (PRP) derivatives in the treatment of venous ulcers. During the selection phase of the RCT, the recurrence in low hemoglobin concentration among the recruited patients prompted the researchers to extend the checking of hemoglobin levels to the remaining chronic injured patients being treated at the ambulatory.

In this instance, the low hemoglobin concentration could be associated with comorbidities common to chronic ulcer patients, since infectious, inflammatory, traumatic, or neoplastic diseases that persist for more than one or two months are often accompanied by mild to moderate anemia, described in the literature as anemia of inflammation or anemia of chronic disease ${ }^{(2,8-10)}$. In this context, a study showed an association between the severity of diabetic foot ulceration and the decline in hemoglobin ${ }^{(11)}$.

Frequently, literature has referred to lower limb ulcers, sickle cell disease, and thalassemias concomitantly. In this situation, the hemoglobinopathies are already well described in the literature for presenting the lower limb ulcers with severe and complex resolution. However, there is still a gap in the literature concerning the association of anemia due to iron homeostasis disorders and chronic ulcers, justifying the need for further studies to evaluate the presence of ACD in patients with leg ulceration, as in the case of this study.

\section{OBJECTIVE}

This study aims at assessing the presence of anemia in patients with chronic lower limb ulcers based on profile and hematometric indicators.

\section{METHODS}

\section{Ethical Aspects}

The Research Ethics Committee of the Medical School from Fluminense Federal University approved this study. We respected the principles established in Resolution No. 466/2012 of the National Health Council (CNS) from the Ministry of Health and the Declaration of Helsinki, and all participants signed an Informed Consent Form (ICF).

\section{Design, setting and period}

A sectional study, guided by the STROBE checklist, developed in the outpatient clinic of a University Hospital in Rio de Janeiro, Brazil. Data collection was performed from May 2016 to December 2017.

\section{Population or sample: inclusion and exclusion criteria}

Convenience sampling, composed of 64 participants in outpatient monitoring for treating the chronic lower limb ulcers (CLU).

The inclusion criteria for this study were: being 18 years old or older, with no gender distinction, with a chronic lower limb ulcer with an evolution time longer than 12 weeks. Exclusion criteria were: pregnancy, suspicion of ulcer malignancy, or participants who had received a transfusion in the previous three months.

\section{Study Protocol}

Data were obtained from the hematological analyses, for general research of anemia and hemoglobinopathies, in addition to the records contained in the patients' charts and the chronic injury assessment form already in use at the outpatient clinic.

The medical records analysis aimed to evaluate the deficiency anemia history of the 36 participants identified with anemia in this study. The biochemical parameters checked were serum iron, serum ferritin, total iron-binding capacity ( $T I B C)$, transferrin saturation, vitamin B12, and folic acid.

Variables included the patient's socio-demographic and clinical data (gender, age, ulcer evolution period, underlying diseases, and laboratory data).

\section{Hematological Tests}

Whole blood was collected in a vacuum tube with a volume of 4 $\mathrm{mL}$, containing the anticoagulant ethylenediaminetetraacetic acid (EDTA). The blood counts of each patient were performed in the Coulter LH 750 (Beckman Coulter, USA). Hematological parameters analysis obtained through the complete blood count allowed us to identify anemia presence or absence in the patient. Among the parameters analyzed, there are: the hemoglobin dosage, the hematocrit level, the quantification of red blood cells, and the hematometric indexes (MCV - mean corpuscular volume, $\mathrm{MCH}$ - mean corpuscular hemoglobin, and MCHC - mean corpuscular hemoglobin concentration). Table 1, below, shows the reference values of these parameters for adult female and male subjects. 
Table 1 - Reference values of red series, Rio de Janeiro, Brazil

\begin{tabular}{|c|c|c|c|c|c|c|}
\hline & $\mathrm{Hb}(\mathrm{g} / \mathrm{dL})$ & Ht (\%) & $\operatorname{Hm}\left(10^{12} / \mathrm{L}\right)$ & $\operatorname{MCV}(\mathrm{fL})$ & MCH (pg) & $\operatorname{MCHC}(g / d L)$ \\
\hline Adults & $( \pm 2 \mathrm{dp})$ & $( \pm 2 d p)$ & $( \pm 2 d p)$ & $( \pm 2 d p)$ & $( \pm 2 \mathrm{dp})$ & $( \pm 2 \mathrm{dp})$ \\
\hline Women & $14.0(12.0-16.0)$ & $41(36-46)$ & $4.6(4.0-5.2)$ & $90(80-100)$ & $30(26-34)$ & $34(31-37)$ \\
\hline Men & $15.5(13.5-17.5)$ & $47(41-53)$ & $5.2(4.5-5.9)$ & $90(80-100)$ & $30(26-34)$ & $34(31-37)$ \\
\hline
\end{tabular}

\section{RESULTS}

\section{Participant profile and injury history}

The sample consisted of 64 participants, with $36(56.2 \%)$ males, 38 (59.4\%) in the 60 to 80 age group, followed by 20 (31.2\%)

The blood smear preparation (blood film) was made through the manual method by creating clean and degreased smear slides. This examination aimed to analyze the hematological cell morphology, especially the erythrocytes, to check any abnormality associated with the study participants.

The determination of reticulocyte count in the peripheral blood assessed erythropoietic activity. Its conclusion was essential to reveal whether screening for G6PD enzyme deficiency was valid. The percentage measurement and the absolute number of reticulocytes were calculated using the formula ${ }^{(12)}$ :

$$
\text { Percentage }=\frac{\text { Number of reticulocytes in } n \text { fields }}{(n) \times \text { Number of erythrocytes per field }} \times 100 \%
$$

The normal range of reticulocyte count in adults is determined to be between 50 to $100 \times 10^{9} / \mathrm{L}(0.5-2.5 \%)^{(12)}$. Absolute reticulocyte count $=\% \times$ RBC (complete blood count)

Cellulose acetate hemoglobin electrophoresis at alkaline $\mathrm{pH}$ was used to diagnose hemoglobinopathies, which allowed the qualification and quantification of normal hemoglobins and most variants in a fast, simple, and reliable way ${ }^{(12-13)}$. The method was based on the difference in electrophoretic mobility shown by specific abnormal $\mathrm{Hb}^{(14)}$. Patients who revealed some alteration in the $\mathrm{Hb}$ electrophoretic profile in the manual method were forwarded to conduct the same technique, but using an automated method by the laboratory routine of Clinical Hematology, to confirm the finding with exact $\mathrm{Hbs}$ quantification.

A healthy adult individual has $\mathrm{Hb}$ A levels above $95 \%$, Fetal $\mathrm{Hb}$ up to $2,0 \%$ and $\mathrm{Hb} \mathrm{A}_{2}$ of 2,0 to $3,5 \%{ }^{(13)}$. Each hemoglobinopathy type has a different distribution profile of these hemoglobin's proportions.

The RBC sickling test was used to detect the presence of $\mathrm{Hb}$ S by evaluating the sickle cell phenomenon. It was performed by looking for sickled RBCs by light microscopy at 100x magnification. The procedure was repeated after $48 \mathrm{~h}$ to confirm the presence or absence of sickling.

The $\mathrm{Hb} \mathrm{S}$ solubility test has been performed for detection of type $\beta$ thalassemias, mainly in the heterozygous type, using $0,36 \%$ sodium chloride solution ${ }^{(14)}$.

\section{Result Analysis and statistics}

From the collected data, we built a database in an excel spreadsheet for statistical analysis in the programs GraphPad Prism 5 e SPSS ("Statistical Package for the Social Sciences") version 17. Sociodemographic data were analyzed by the tests: Chi-square and Mann-Whitney. We conducted the sample homogeneity check regarding gender, age, and underlying disease data. The ANOVA statistical test was used to compare the anemia classification groups and the unpaired T-test to compare the groups from 2 in 2 , considering the parameters by a normal distribution. The values are deemed statistically significant when the $p$-value is less than 0.05 . For correlation, it was investigated if the samples obeyed the normality curve and, depending on this, we applied the Spearman or Pearson correlation. between 30 and 59 years old, and 6 (9.4\%) over 80 years old.

Regarding the underlying diseases, 56 (87.5\%) participants had chronic diseases. Among the most frequent comorbidities, 42 (65.6\%) participants had Systemic Arterial Hypertension (SAH), and 31 (48.4\%) had Diabetes Mellitus (DM).

As for the injury background, 52 (81.2\%) participants had venous ulcers. Although venous ulcers were the most prevalent, 7 (10.9\%) had diabetic ulcers, and 5 (7.8\%) had arterial ulcers.

The average time of active ulceration was six years. Ulcer recurrence was frequent in 34 (53.13\%) participants, and 24 (32.8\%) had a family history of chronic lower limb ulcers.

\section{Anemia Findings}

More than half of the participants had hemoglobin levels below the reference value established by the WHO, as shown in Table 2 . From the $\mathrm{CBC}$ and reticulocyte count, the participants were divided primarily into two groups, those with or without anemia condition.

From the $\mathrm{CBC}$ and reticulocyte count, it was possible to identify anemia in 36 (56.2\%) participants in different degrees of severity. The hematrimetic parameters indicated that 27 (75.0\%) had normochromic and normocytic anemia, 8 (22.2\%) had hypochromic and microcytic anemia, and only one (2.7\%) participant had macrocytic anemia (Table 2). characterization, Rio de Janeiro, Brazil, 2016-2017

\begin{tabular}{lcc}
\hline Anemia & n & (\%) \\
\hline General & 36 & 56.2 \\
Normochromic and normocytic & 27 & 75.0 \\
Hypochromic and microcytic & 8 & 22.2 \\
Macrocytic & 1 & 2.7 \\
\hline
\end{tabular}

Table 3 shows the mean value found in the hemograms of the anemic patients in general and relevant to each type of anemia previously characterized.

The hemoglobin value was significantly different between the normocytic/normochromic and microcytic/hypochromic anemia profiles $(p=0.017)$. In this case, it is considered that individuals with a microcytic/hypochromic profile presented a more impacting reduction in hemoglobin concentration (Table 3 ).

Other parameters showed differences in the global analysis (ANOVA) and comparative tests between the groups. Results revealed an altered hematimetric index profile, as expected for each group, based on their classification.

Figure 1 shows the incidence of the investigated hereditary anemias in the participants' group. 64 participants were analyzed for hemoglobinopathies and membranopathies. For G6PD deficiency (enzymopathies), 51 participants were considered. Regarding the presence of hemoglobinopathies, only 3 (4.69\%) participants presented sickle cell trait out of the total of 64 participants.
Table 2 - Determination of Anemia Incidence in the participants and its 
Table 3 - Mean CBC values of anemic patients in general and by anemia profile, Rio de Janeiro, Brazil, 2016-2017

\begin{tabular}{|c|c|c|c|c|c|}
\hline \multirow[b]{2}{*}{ Parameters } & \multicolumn{4}{|c|}{ Anemic patients** } & \multirow[b]{2}{*}{$p$ value } \\
\hline & General & $\begin{array}{l}\text { Normocytic and } \\
\text { Normochromic }\end{array}$ & $\begin{array}{l}\text { Microcytic and } \\
\text { Hypochromic }\end{array}$ & Macrocytic* & \\
\hline Red blood cells $\left(\times 10^{6}\right)$ & $4.06( \pm 0.64)$ & $3.99( \pm 0.55)$ & $4.43( \pm 0.78)$ & 3.25 & $>0.08^{a, b, c}$ \\
\hline Hemoglobin (g/dL) & $10.88( \pm 1.72)$ & $11.24( \pm 1.39)$ & $9.58( \pm 2.17)$ & 11.4 & $0.017^{c}$ \\
\hline Hematocrit (\%) & $34.14( \pm 5.23)$ & $34.97( \pm 4.50)$ & $31.40( \pm 6.69)$ & 33.5 & $<0.0001^{\mathrm{a}, \mathrm{b}, \mathrm{c}}$ \\
\hline Reticulocytes (\%) & $1.12( \pm 0.66)$ & $1.01( \pm 0.59)$ & $1.39( \pm 0.81)$ & 1.79 & $>0.08^{a, b, c}$ \\
\hline Mean Corpuscular Volume (fL) & $84.44( \pm 9.14)$ & $87.87( \pm 3.63)$ & $70.56( \pm 7.53)$ & 102.9 & $<0.0003^{a, b, c}$ \\
\hline Mean Corpuscular Hemoglobin (pg) & $26.95( \pm 3.64)$ & $28.28( \pm 1.43)$ & $21.46( \pm 2.91)$ & 35.1 & $<0.0003^{\mathrm{a}, \mathrm{b}, \mathrm{c}}$ \\
\hline $\begin{array}{l}\text { Mean Corpuscular Hemoglobin } \\
\text { Concentration (g/dL) }\end{array}$ & $31.83( \pm 1.25)$ & $32.19( \pm 0.82)$ & $30.33( \pm 1.19)$ & 34.1 & $<0.004^{a, b, c}$ \\
\hline Platelets $\left(\times 10^{3}\right)$ & $286.64( \pm 106.66)$ & $279.78( \pm 60.76)$ & $341.00( \pm 166.83)$ & 37 & $>0.334^{\mathrm{a}, \mathrm{b}, \mathrm{c}}$ \\
\hline
\end{tabular}

* values referring to the single patient with macrocytic anemia ; ** Mean ( \pm Standard Deviation); ${ }^{\mathbf{a}}$ Oneway ANOVA statistic; ${ }^{\mathbf{b}}$ Unpaired T-test comparing general x microcytic and hypochromic groups; ' ${ }^{*}$ Unpaired T-test comparing normocytic and normochromic x microcytic and hypochromic groups.

\section{Review in the participants' medical records}

Out of 36 anemic participants, 22 (61.1\%) had no record of these complementary tests in medical records or had recent records. Thus, only 14 (38.8\%) had the deficiency anemia research recorded in their medical records because they were followed by other outpatient clinics and, at some point, revealed a history of persistent anemia.

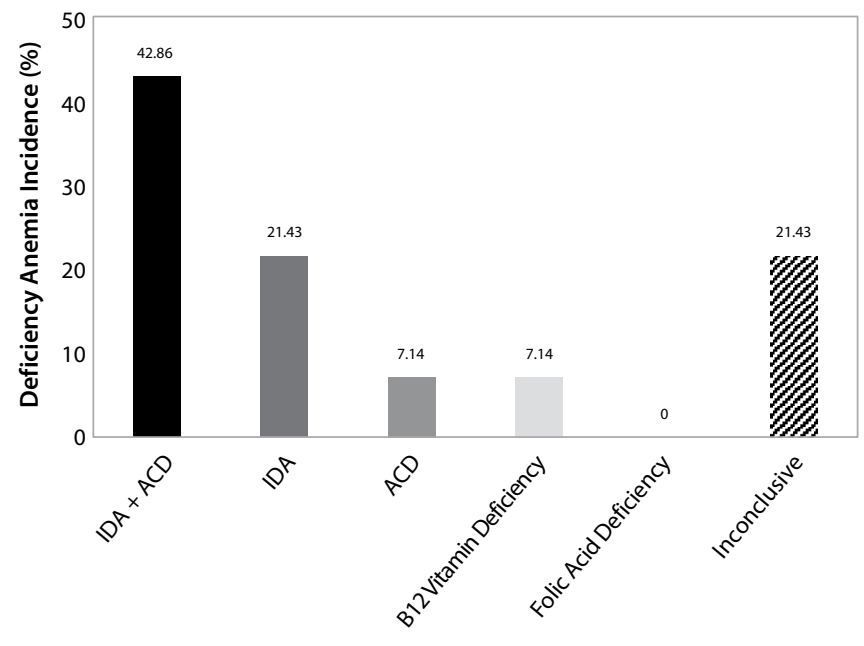

Figure 1 Incidence of hereditary anemias examined in the group of participants

\section{Correlation Analysis}

From the results shown in figure 2 , it can be noticed that the $\mathrm{Hb}$ values are not correlated to the period of active ulceration in the 36 participants identified as anemic.

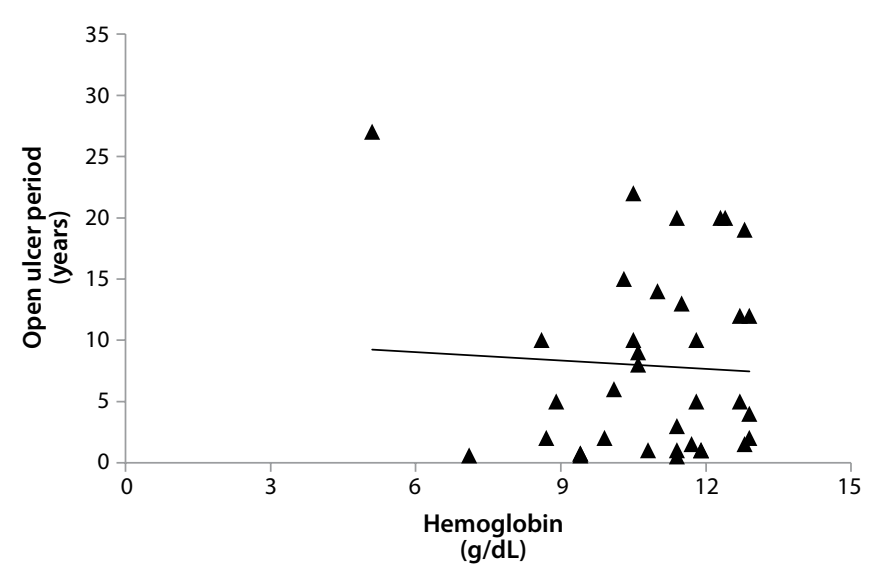

Spearman's correlation test for normal distribution $(n=36)(p=0.408)$

Figure $\mathbf{2}$ Correlation of $\mathrm{Hb}$ values with open ulcer period in anemic patients
Among those 14 participants analyzed for alterations in iron metabolism, it was possible to identify $3(21.4 \%)$ with iron deficiency anemia (IDA), 1 (7.14\%) with anemia of chronic disease (ACD), and 6 (42.86\%) with concomitant iron deficiency anemia and anemia of chronic disease (IDA + ACD). Concerning vitamin B12 and folic acid deficiencies, we found only one (7.14\%) participant with vitamin B12 deficiency.

\section{DISCUSSION}

Among the ulcers found on the lower limbs, venous ulcers are the most prevalent, with chronic venous insufficiency being the main cause for its appearance ${ }^{(15)}$. Treatment should be focused on elimination and/or control of causal factors, systemic support, and appropriate topical treatment. The patient's general condition needs to be considered with an evaluation of nutritional support, age group, associated diseases, medications use, metabolic disorders, and psychological effects.

In general, patients with chronic lower limb ulcers have associated diseases that determine the injury etiology, such as diabetes, hypertension, and chronic venous insufficiency ${ }^{(16)}$. Aggravation of these diseases directly interferes in the tissue repair process, chronifying the inflammatory phase and prolonging the time of wound evolution, as is the case of the participants in this study.

Frequently, when patients are asked during nursing consultations about associated diseases, anemia is not mentioned, but the results of the blood counts show that it affected $56.2 \%$ of the participants. This finding is relevant given that iron deficiency can interfere with wound healing ${ }^{(11)}$ and consequently in the nursing care of patients with lower limb ulcers.

Generally, the diagnosis of anemia is based on laboratory tests as patients are often asymptomatic or have nonspecific symptoms ${ }^{(17)}$. Although asymptomatic, anemia can contribute to worsening symptoms of underlying diseases, faster progression, worse prognosis, and interference with quality of life $\mathrm{e}^{(17)}$.

Nursing plays an essential role in the treatment of these patients, regarding the therapeutic procedures involving the diagnosis assessment, the healing process, and the prevention of pathology-related injuries. This prevention should occur through the construction/application of new technical interventions in nursing and health care ${ }^{(18)}$.

In cases of iron deficiency/anemia or inflammation, when serum hepcidin levels are elevated, the hepcidin/ferroportin 
interaction can increase iron concentration in cells, particularly in macrophages; this can also have a detrimental effect on wound healing ${ }^{(11)}$. Iron deficiency without inflammation can affect one of the final stages of wound healing, such as remodeling.

It is noteworthy that in the literature, anemia in patients with CLU is predominantly related to sickle cell anemia, which cannot be considered in this study since only 3 (4.69\%) participants presented sickle cell traits.

Inflammatory anemia is normocytic and normochromic or hypochromic, and it may also occur hypochromia and microcytosis in 20 to $30 \%$ of patients with chronic disease ${ }^{(2,19)}$. In this perspective, most anemic individuals' normocytic and normochromic profile reveals congruence with the anemia of chronic disease since acute and chronic inflammatory conditions are configured as the main causes of anemia in the elderly and people with chronic diseases ${ }^{(20)}$.

The term Anemia of Chronic Disease (ACD) was first proposed by Cartwright in 1966 after several years of studying the infection and anemia binomial ${ }^{(21)}$. Out of the multiple mechanisms involved in the ACD's etiopathogenesis, the three main ones have decreased RBC survivability, inadequate marrow response to anemia, and disturbed iron metabolism ${ }^{(21)}$.

In general, ACD is found in patients whose underlying disease provokes an immune/inflammatory response leading to reduced iron absorption at multiple sites ${ }^{(9)}$. In this case, ACD could be a pathophysiological consequence of the body's attempt to reduce iron availability as a nonspecific defense measure against infectious agents $^{(1-2,7)}$.

For the elderly, it is suggested that reactive oxygen species (ROS) would be at the center of this position, causing the exacerbated apoptosis of erythrocytes in this population and consequently anemia. The comorbidities and inflammation, also characteristic of this stage, would be "feeding" this whole process, worsening the anemia scenario because they are also associated with high concentrations of ROS. However, this context is yet to be proven, despite the evidence of these associations ${ }^{(22)}$.

It is considered the second most common cause of anemia and the leading cause in hospitalized anemic patients, particularly when analyzing patients over 65 years ${ }^{(9-10,23)}$. An analysis of anemic patients with no history of blood loss showed that $52 \%$ of them fulfilled laboratory criteria for the diagnosis of ACD (decreased serum iron and increased serum ferritin) ${ }^{(24)}$.

Anemia of chronic disease cause is complex and multifactorial, being associated with an underlying chronic disease and mainly with alterations in the iron balance derived from the immune system activation ${ }^{(22)}$. As for the clinical features, the symptoms present are usually related to the underlying disease and not to the anemia itself. The anemia develops within the first 30 to 90 days, usually does not progress, and often normalizes with treating underlying disease ${ }^{(21)}$.

Another relevant aspect is the positive correlation between anemia and activity and/or intensity of the underlying disease, in other words, the greater the intensity of the patient's symptoms, the greater the degree of anemia and, once treatment is instituted, the anemia tends to improve and even normalize the hemoglobin values ${ }^{(21)}$.

Although prevalent in the elderly, the diagnosis of ACD is a challenge, mainly because it may coexist with other anemia causes, especially iron-deficiency anemia. However, some features are relevant, and briefly, it can be said that ACD is mild anemia with a normocytic, normochromic profile, characterized by low reticulocyte indices, low serum iron, and low total iron-binding capacity, with normal or increased ferritin, in a patient with a systemic disease with an inflammatory component ${ }^{(17)}$.

The anemia expressivity within this group presupposes the importance of investigating it in greater detail, especially regarding the wound healing process retardation. Thus, it would be possible to advance the knowledge about iron deficiency in the healing of cutaneous wounds and contribute to improving chronic ulcer healing process and the quality of patients' lives.

We recommend a holistic approach for all the aspects mentioned, in which we consider more than the wound itself, but also life habits and underlying diseases, relating all healthcare areas and applying interdisciplinary knowledge for more effective treatment ${ }^{(25)}$.

\section{Contributions to Nursing}

The prevalence of anemia is considerable in the group of patients with chronic ulcers of the lower limbs, which suggests that its laboratory investigation in this population cannot be ruled out, aiming at better clinical support, with the implementation of more effective care in the treatment of chronic ulcers, besides helping in the recovery of the global health of these patients.

\section{Limitations of the Study}

It is important to note that the diagnosis of inflammatory anemia is clinical and requires excluding causes, which can be difficult since patients may have one or more associated diseases. Moreover, anemia itself can be multifactorial, with coexisting iron, vitamin, and other deficiencies ${ }^{(26)}$. In this case, a complementary exam to quantify the hepcidin circulating levels could help in the differential diagnosis of anemia ${ }^{(27)}$, nevertheless, the high cost of this exam made its performance unfeasible in this study.

\section{CONCLUSION}

Results show that low $\mathrm{Hb}$ concentration is recurrent among patients with chronic ulcers of the lower limbs, characterizing a picture of anemia, whose profile reveals congruence to anemia of the chronic disease. There was no correlation between $\mathrm{Hb}$ values and the time of active ulcer in the 36 participants identified as anemic. However, participants' number should be increased in future studies to try to determine some trend line. The iron metabolism disorder may interfere in the healing process of chronic ulcers, indicating the need for nurses to investigate such data during nursing consultations based on laboratory and clinical exams. We suggest laboratory investigation in this population, aiming at better clinical support of these patients. The number of individuals presenting low hemoglobin values seems to be underestimated and needs to be clarified in order to establish links between such findings and the delay in the healing process of wounds. 


\section{REFERENCES}

1. Metzgeroth G, Hastka J. Iron deficiency anemia and anemia of chronic diseases. Internist. 2015;56(9):978-88. https://doi.org/10.1007/ s00108-015-3711-2

2. Carvalho MC, Baracat EC, Sgarbieri VC. Anemia ferropriva e anemia da doença crônica: distúrbios do metabolismo de ferro. Segur Aliment Nutr. 2006;13(2):54-63. https://doi.org/10.20396/san.v13i2.1832

3. Hoffbrand AV, Moss PAH. Fundamentos em Hematologia. $7^{a}$ ed. Porto Alegre: Artmed; 2018. 384p.

4. World Health Organization (WHO). Safe and rational clinical use of blood. Switzerland: The clinical use of blood in obstetrics, paediatrics, surgery and anaesthesia, trauma and burns [Internet]. 1998 [cited 2020 May 25]. Available from: https://www.who.int/bloodsafety/ clinical_use/en/Manual_EN.pdf

5. World Health Organization (WHO). World health statistics [Internet]. Switzerland 2015 [cited 2020 May 25]. Available from: https://apps.who. int/iris/handle/10665/170250

6. Kassebaum NJ, The global burden of anemia. Hematol Oncol Clin N Am. 2016;30:247-308. https://doi.org/10.1016/j.hoc.2015.11.002

7. Nairz M, Theurl I, Wolf $D$, Weiss $G$. Iron deficiency or anemia of inflammation: differential diagnosis and mechanisms of anemia of inflammation. Wien Med Wochenschr. 2016;166(13-14):411-23. https://doi.org/10.1007/s10354-016-0505-7

8. Gangat N, Wolanskyj AP. Anemia of chronic disease. Semin Hematol. 2013;50(3):232-8. https://doi.org/10.1053/j.seminhematol.2014.01.001

9. Madu, AJ e Ughasoro, MD (2016). Anemia of chronic disease: an in-depth review. Med Princ Pract. 2017;26(1):1-9. https://doi. org/10.1159/000452104

10. Poggiali E, Migone De Amicis M, Motta I. Anemia of chronic disease: a unique defect of iron recycling for many different chronic diseases. Eur J Intern Med. 2014;25(1):12-7. https://doi.org/10.1016/j.ejim.2013.07.011

11. Wright JA, Richards T, Srai SK. The role of iron in the skin and cutaneous wound healing. Front Pharmacol. 2014;5:156. https://doi. org/10.3389/fphar.2014.00156

12. Bain BJ, Bates I, Laffan MA. Dacie and Lewis practical haematology. $12^{\mathrm{a}}$ ed. Inglaterra: Elsevier; 2017. 600p. https://doi.org/10.1016/ B978-0-7020-6696-2.00003-5

13. Ministério da Saúde (BR). Agência Nacional de Vigilância Sanitária (ANVISA). Manual de Diagnóstico e Tratamento das Doenças Falciformes [Internet]. Brasília: Ministério da Saúde, 2002. [cited 2020 Dec 13]. Available from: http://bvsms.saude.gov.br/bvs/publicacoes/anvisa/ diagnostico.pdf

14. Universidade Estadual Paulista (UNESP). Protocolos de metodologias laboratoriais clássicas para o diagnóstico de hemoglobinopatias. São José do Rio Preto: Instituto de biociências, letras e ciências exatas, jul. 2003 [cited 2021 Jan 15]. Available from: https://docplayer.com. br/3259505-Protocolos-de-metodologias-laboratoriais-classicas-para-o-diagnostico-de-hemoglobinopatias.html

15. Oliveira BGRB, Silva JA, Silveira IA, Santos NC, Carvalho MR. Instrumentos de avaliação clínica para úlceras de perna. Enferm Atual [Internet]. 2019 [cited 2020 May 25];87(Ed Esp):1-9. Available from: http://revistaenfermagematual.com/index.php/revista/article/view/171

16. Lentsck MH, Baratieri T, Trincaus MR, Mattei AP, Miyahara CTS. Qualidade de vida relacionada a aspectos clínicos em pessoas com ferida crônica. Rev Esc Enferm USP. 2018;52:e03384. https://doi.org/10.1590/s1980-220x2017004003384

17. Mayhew Maren. Anemia of Chronic Disease in the Elderly. J Nurs Pract. 2006;2(4):261-7. https://doi.org/10.1016/j.nurpra.2006.03.002

18. Joaquim FL, Silva RMCRA, Garcia-Caro MP, Cruz-Quintana F, Pereira ER. Impact of venous ulcers on patients' quality of life: an integrative review. Rev Bras Enferm. 2018;71(4):2021-9. https://doi.org/10.1590/0034-7167-2017-0516

19. Chaparro CM, Suchdev PS. Anemia epidemiology, pathophysiology, and etiology in low- and middle-income countries. Ann NY Acad Sci. 2019;1450(1):15-31. https://doi.org/10.1111/nyas.14092

20. Fraenkel PG. Anemia of inflammation: a review. Med Clin North Am. 2017;101(2):285-96. https://doi.org/10.1016/j.mcna.2016.09.005

21. Cançado RD, Chiattone CS. Anemia de doença crônica. Rev Bras Hematol Hemoter. 2002;24(2):127-36. https://doi.org/10.1590/ S1516-84842002000200009

22. Röhrig G. Anemia in the frail, elderly patient. Clin Interv Aging. 2016;11:319-26. https://doi.org/10.2147/CIA.S90727

23. Cartwright GE, Lee GR. The anaemia of chronic disorders. Br J Haematol.1971;21:147-52. https://doi.org/10.1111/j.1365-2141.1971.tb03424.x

24. Cash JM, Sears DA. The anemia of chronic disease: spectrum of associated diseases in a series of unselected hospitalized patients. Am J Med. 1989;87(6):638-44. https://doi.org/10.1016/s0002-9343(89)80396-1

25. Sachett JAG, Montenegro CS. Perfil epidemiológico dos pacientes atendidos pelo programa Melhor em Casa. ESTIMA Braz J Enterostomal Ther. 2019;17:1-9. https://doi.org/10.30886/estima.v17.737_PT

26. Stein BL. A anemia da inflamação. J Clin Rheumatol. 2012;18(8):437-42. https://doi.org/10.1097/RHU.0b013e318278f553

27. Antunes SA, Canziani MEF. Hepcidina: um importante regulador do metabolismo de ferro na doença renal crônica. J Bras Nefrol. 2016;38(3):351-55. https://doi.org/10.5935/0101-2800.20160053 